\title{
Threatened pond endemicity on an oceanic island: the presence of an exotic fish
}

\author{
Margarita Florencio ${ }^{1,2,3, *}$ and Lucas Lamelas-López ${ }^{1,2}$
}

${ }^{1}$ CE3C-Centre for Ecology, Evolution and Environmental Changes. Azorean Biodiversity Group. Universidade dos Açores, Departamento de Ciências Agrárias, Angra do Heroísmo, Açores, Portugal.

${ }^{2}$ CITA-A. Universidade dos Açores, Departamento de Ciências Agrárias, Angra do Heroísmo, Açores, Portugal.

${ }^{3}$ Present address: Departamento de Ecologia, Universidade Federal de Goiás, 74001-970, Goiânia, Goiás, Brazil.

*Corresponding author: margarita@ebd.csic.es; mflorenciodiaz@gmail.com

Received: 06/08/2014

Accepted: 21/12/2015

\begin{abstract}
Threatened pond endemicity on an oceanic island: the presence of an exotic fish

The EU Water Framework Directive (WFD) prioritises the importance of freshwater conservation areas in the Macaronesian Islands (Azores, Madeira, Canarias and Cape Verde). However, few studies have investigated these freshwater areas. Therefore, research must focus on establishing reference sites for aquatic conservation. We analyse the potential effects of water characteristics and the presence of an exotic predator fish, Gambusia holbrooki (Girard, 1859), on the abundance of an endemic aquatic beetle, Hydroporus guernei (Régimbart, 1891), on an oceanic island. During ten successive months, we sampled the abundance of $H$. guernei using a protocol that targeted macroinvertebrates in three temporary and two permanent ponds on Terceira Island, Azores archipelago. We also recorded the abundance of G. holbrooki, which was observed for the first time on the island, as well as the environmental characteristics of these ponds. H. guernei contributes a high degree of endemicity to the temporary ponds, while the exotic species only occurred in one permanent pond. The results of multiple regressions suggest that the abundance of $H$. guernei can be mainly explained by the conductivity $(19.1 \%)$ and the abundance of G. holbrooki (14.5\%). These results suggest that $H$. guernei is a species with a narrow tolerance to environmental changes. In addition, its abundance may be affected by the presence of $G$. holbrooki. We suggest that urgent monitoring actions be taken to control the abundance of this exotic fish in these ponds, thereby guaranteeing the conservation of endemic H. guernei populations.
\end{abstract}

Key words: Acidic waters, Azores, endemic species, Gambusia holbrooki, Hydroporus guernei, aquatic macroinvertebrates, temporary ponds.

\section{RESUMEN}

Amenazada la endemicidad de las lagunas en una isla oceánica: la presencia de un pez exótico

La Directiva Marco del Agua (WFD) de la UE destaca la importancia para la conservación de los humedales en las islas macaronésicas (Azores, Madeira, Canarias y Cabo Verde). Sin embargo, sólo unos pocos estudios han considerado estos humedales, siendo esencial llevar a cabo estudios enfocados en establecer puntos de referencia para la conservación acuática. En este estudio analizamos el posible efecto de las características del agua y de la presencia de un pez exótico depredador, Gambusia holbrooki (Girard, 1859), sobre la abundancia de un coleóptero acuático endémico, Hydroporus guernei (Régimbart, 1891), en una isla oceánica. Durante diez meses sucesivos, muestreamos la abundancia de $\mathrm{H}$. guernei usando un protocolo dirigido al muestreo de macroinvertebrados, en tres lagunas temporales y dos permanentes, en la isla Terceira, archipiélago de las Azores. También muestreamos la abundancia de G. holbrooki, observada por primera vez en la isla de estudio, y las características ambientales de estas lagunas. Los individuos de $\mathrm{H}$. guernei atribuyeron un alto grado de endemicidad a las lagunas temporales, mientras que el pez exótico solo apareció en una laguna permanente. Después de realizar regresiones múltiples, detectamos que la abundancia de $\mathrm{H}$. guernei fue principalmente explicada por la conductividad (19.1\%) y por la abundancia de G. holbrooki (14.5\%). Estos resultados sugieren que $\mathrm{H}$. guernei es una especie con una estrecha tolerancia ambiental, y que su abundancia se puede ver afectada por la ocurrencia de G. holbrooki. Sugerimos que 
se deberían llevar a cabo acciones urgentes de monitoreo en estas lagunas para controlar la abundancia de este pez exótico, y garantizar así la conservación de las poblaciones endémicas de H. guernei.

Palabras clave: Aguas ácidas, Azores, especies endémicas, Gambusia holbrooki, Hydroporus guernei, macroinvertebrados acuáticos, lagunas temporales.

\section{INTRODUCTION}

The EU Water Framework Directive (WFD) prioritises freshwater conservation areas in the Macaronesian region, which comprises Azores, Madeira, Canarias and Cape Verde Islands. The high level of endemism associated with the Macaronesian macroinvertebrate fauna creates considerable conservation value in these aquatic habitats. However, the lack of information at reference sites hinders the establishment of proper conservation guidelines (Hughes \& Malmqvist, 2005). Particularly, temporary ponds, which undergo re- current inundation and unpredictable desiccation, are considered priority habitats for conservation by the European Union (code 3170 of the Habitat Directive). Temporary ponds harbour singular species. These species must cope with pond desiccation by adjusting their life cycles based on the variable duration of pond inundation (Williams, 2006). In contrast to permanent ponds, temporary ponds are characterised by the absence of top-predator fishes, which cannot cope with pond desiccation (Wellborn et al., 1996). The introduction of exotic species has contributed to declining global biodiversity (Vitousek et al., 1996,

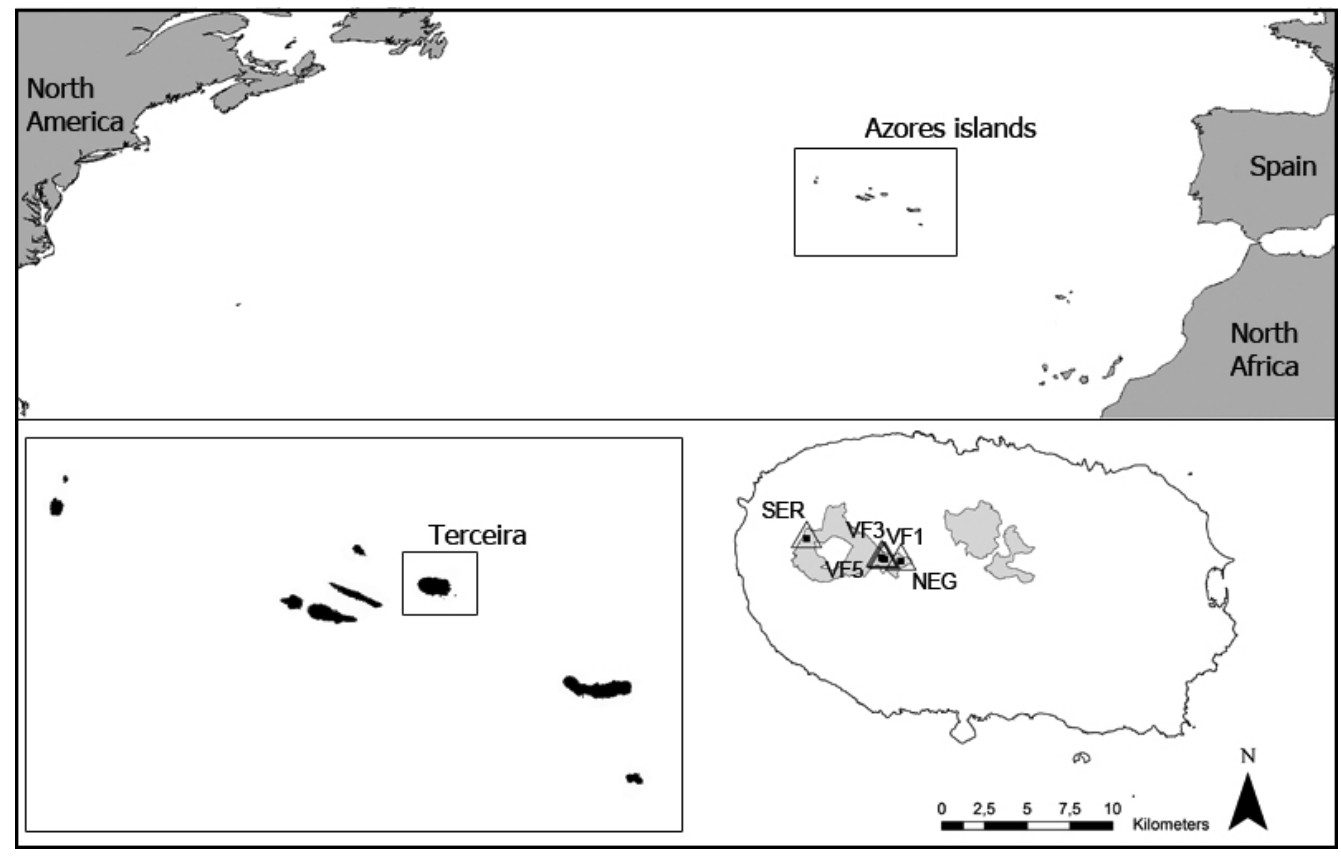

Figure 1. Map of the Azores archipelago showing the five study ponds on Terceira Island (VF1, VF3 and VF5 are temporary ponds, and NEG and SER are permanent ponds). The Natural Forest Reserve (NFR) in "Serra de Santa Bárbara and Mistérios Negros" (grey area) and the location of the Terceira Island in the Azores archipelago are also indicated. Localización del archipiélago de las Azores y de las cinco lagunas de estudio en la isla Terceira (VF1, VF3 y VF5 son temporales, y NEG y SER son permanentes); también se indica la Reserva Natural Forestal (NFR) de "Serra de Santa Bárbara e Mistérios Negros" (área gris) y la localización de la isla Terceira en el archipiélago de las Azores. 
1997; Cassey et al., 2005). This biodiversity loss has extended to aquatic ecosystems, resulting in changes to biodiversity patterns (Hermoso et al., 2012) and habitat quality degradation (Arribas $e t$ al., 2014). Specifically, the introduction of exotic species at high trophic levels may promote accentuated changes on oceanic islands where native biotas have often evolved without predators (Whittaker \& Fernández-Palacios, 2007).

In our study, we analysed the abundance of the aquatic beetle Hydroporus guernei (Régimbart, 1891), which has been described as an endemic species of the Azores archipelago by Alluaud (1891), in three temporary and two permanent ponds on Terceira Island. We analysed the effects of an exotic predator fish, Gambusia holbrooki (Girard, 1859), observed for the first time on the study island, versus other environmental pond characteristics. We hypothesised that the predator fish would strongly affect the abundance of the endemic beetle in permanent ponds compared to temporary ponds, which would be less susceptible to the introduction of the exotic fish.

\section{METHODS}

\section{Study site}

The Azores archipelago is located between $36^{\circ}$ $45^{\prime}-39^{\circ} 43^{\prime} \mathrm{N}$ and $24^{\circ} 45^{\prime}-31^{\circ} 17^{\prime} \mathrm{W}$. It comprises nine islands separated in three groups: the western group (Flores and Corvo), the central group (Faial, Pico, S. Jorge, Terceira and Graciosa) and the eastern group (S. Miguel and S. Maria), in addition to small islets. The temperate oceanic climate is characterised by stable temperatures, substantial precipitation and high relative atmospheric humidity, which can reach more than $95 \%$ in high-altitude native forests. This study was conducted between November 2013 and August 2014 in three temporary ponds, VF1, VF3 and VF5, and two permanent ponds, Negro (NEG) and Serreta (SER) (Fig. 1; the UTM geographical coordinates X, Y in zone 26S are 475712, 4287838 for VF1; 475605, 4287864 for VF3; 475505, 4287935 for VF5; 476639 , 4287739 for NEG; and 471127, 4289052 for
SER). Among the temporary ponds, VF1 was dry in June, VF5 was dry in July and VF5 contained water throughout the sampling period; although, it was dry in October before the study began. The ponds were all located in the Natural Forest Reserve (NFR) created under Portuguese law $\mathrm{n}^{\mathrm{o}}$ 27/88/A within the Natural Park of Terceira in Serra de Santa Bárbara and Mistérios Negros. This NFR encompasses the majority of the native forest area on Terceira Island (Fig. 1), currently accounting for $6 \%$ of the island area.

\section{Pond characteristics and sampling procedures}

Study sites were sampled monthly. Electrical conductivity at $20^{\circ} \mathrm{C}$ (Multi-range Conductivity meter HANNA HI 98127), $\mathrm{pH}$ (pH meter HANNA HI 98311), dissolved $\mathrm{O}_{2}$ concentration and temperature $\left({ }^{\circ} \mathrm{C}\right)$ (Oxi 315i WTW) were measured in situ in the water column. We obtained two replicates of each measurement per pond and per month. An average value was used given the homogeneity of the measures. We collected $330 \mathrm{ml}$ of surface water to measure the total $\mathrm{P}$ concentration in the water column (TP) using acid digestion in the laboratory (Golterman, 2004). We sampled individuals of Hydroporus guernei (adults and larvae) using a sampling procedure that targets macroinvertebrates. The method utilized a $40 \times 25 \mathrm{~cm}$ dip net with a $1 \mathrm{~mm}$ mesh size. Approximately $1.5 \mathrm{~m}$ stretches of water were netted in each sampling unit. We sampled all available microhabitats in each pond based on differences in aquatic plant cover and depth (Heyer et al., 1994), extending from the littoral zone to the deepest point of the pond when accessible. The dip netting efficiency was generally better in small ponds (Heyer et al., 1994). Therefore, we assigned a specific number of sampling units to each pond, with larger numbers given to larger ponds (Florencio et al., 2009). The study consisted of 557 total sampling units, ranging from 5 to 19 sampling units per pond. Species sorting was performed in the field. Most adult individuals of $H$. guernei were released back into the pond. Only unidentified larvae were preserved in $70 \%$ ethanol for subsequent identification in the laboratory. Using the described 
sampling procedure that targets macroinvertebrates, we also captured individuals of Gambusia holbrooki, which were identified and quantified.

\section{Data analyses}

We pooled adults and larvae together as individuals of $H$. guernei. We then calculated the average number of individuals captured per pond and per month (hereafter called "abundance of H. guernei" for simplicity). The average number of individuals of $G$. holbrooki per pond and per month was also calculated (hereafter called "abundance of G. holbrooki" for simplicity). Because we could not record the dissolved $\mathrm{O}_{2}$ concentration in February and March, we replaced missing values with the pond-based mean of that variable (e.g., Leps \& Smilauer, 2003). The abundance of $H$. guernei was $\log _{e}(x+1)$ transformed to obtain normality. This parameter was then used as a response variable in the statistical analyses. We then used the abundance of $G$. holbrooki and the pond characteristics as predictors using general linear models for multiple regressions (Legendre \& Legendre, 1998; Statistica v. 8). To avoid collinearity, we excluded $\mathrm{pH}$ from the statistical analysis due to the correlation with the abundance of $G$. holbroo$k i$ (Spearman correlation $=0.76)$. Type III sums of squares were used and standardised $\beta$-coefficients were estimated to measure both the relative contribution of each variable (electrical conductivity, dissolved $\mathrm{O}_{2}$ concentration, total $\mathrm{P}$ concentration in the water column and the abundance of $G$. holbrooki) and their relationships to the abundance of $H$. guernei.

\section{RESULTS AND DISCUSSION}

\section{Pond and biological characteristics}

The ponds were characterised as well-oxygenated waters (Table 1). Low water conductivities $(<109 \mu \mathrm{S} / \mathrm{cm})$ indicate that the ponds were primarily flooded with rainwater. A reduced TP was detected in the water column, likely due to water dilution as a consequence of persistent rainfall.
TP only peaked in a permanent pond (NEG) during June. This result may have been due to the combination of a low water level and windy days (pers. observation), which favour the suspension of particles from the sediment. Rainfall may have also contributed to the acidic waters detected in all ponds across the sampling months, resulting in a $\mathrm{pH}$ of $<4.2$ in temporary ponds (Table 1 ). However, other factors may have contributed to such low $\mathrm{pH}$ values in the study ponds, e.g., the presence of basalt deposits of volcanic origin (Timperley \& Vigor-Brown, 1986; Delmelle \& Bernard, 1994; Bernard et al., 2004), humic substances washed from upland soils into the study ponds (Florencio et al., 2013) and secretions by the organic acidic molecules in Sphagnum (Clymo, 1964; Mendes \& Dias, 2001).

Adults and larvae of $H$. guerne $i$ were observed simultaneously during the sampling period, peaking in abundances during three different months (Table 1). The abundance variations are likely associated with annual rainfall patterns. In November, the temporary ponds had recently been inundated; however, precipitation was still low compared to December. In February, after two successive months with little rainfall, the water level reduction may have concentrated high abundances of $H$. guernei. In May, ponds also exhibited reduced water levels due to minimal rainfall, followed by desiccation in two temporary ponds in the successive months.

\section{Pond endemicity}

In total, we detected 266 individuals (176 adults and 90 larvae) of $H$. guernei in the ten months of sampling (Table 1), highlighting the high endemicity of the Azorean ponds (e.g., Raposeiro et al., 2012). In temporary ponds, we recorded 0.9 ( \pm 1.9 SD) individuals of $H$. guernei on average per pond and per month, while only $0.1( \pm 0.3$ SD) individuals on average were detected in the permanent ponds. This result suggests that $H$. guernei contributes a high degree of endemicity to the temporary ponds. In this study, we have reported the introduction of the mosquitofish Gambusia holbrooki (Girard 1859) for the first time on Terceira Island. This invasive species 
Table 1. Average number of $H$. guernei individuals per pond based on adults and larvae. The average number of Gambusia holbrooki individuals per pond and the environmental characteristics of the temporary and the permanent ponds are also indicated (the blanks indicate the dissolved oxygen concentration values that were not measured; NEG and SER are the permanent ponds; VF1, VF3 and VF5 are the temporary ponds; VF1 was dry in June; VF1 and VF5 were dry in July and August). Número medio de individuos de H. guernei por laguna de adultos y de larvas. También se indica el número medio de individuos de Gambusia holbrooki por laguna y las características ambientales de las lagunas temporales y permanentes (los espacios en blanco indican aquellos valores de la concentración de oxígeno disuelto que no se midieron; NEG y SER son las lagunas permanentes y VF1, VF3 y VF5 son las lagunas temporales; VF1 aparece seca en Junio, y VF1 y VF5 también en Julio y Agosto).

\begin{tabular}{|c|c|c|c|c|c|c|c|c|}
\hline Month & Pond & $\begin{array}{l}\text { H. guernei } \\
\text { Adult }\end{array}$ & $\begin{array}{l}\text { H. guernei } \\
\text { Larvae }\end{array}$ & $\begin{array}{c}\text { Averaged abundance of } \\
\text { Gambusia }\end{array}$ & $\mathrm{TP}(\mu \mathrm{g} / \mathrm{L})^{a}$ & $\mathrm{O}_{2}(\mathrm{mg} / \mathrm{L})^{b}$ & $\mathrm{pH}$ & $\begin{array}{l}\text { Conductivity } \\
(\mu \mathrm{S} / \mathrm{cm})\end{array}$ \\
\hline \multicolumn{9}{|c|}{ November } \\
\hline & NEG & 0 & 0 & 2.57 & 66.90 & 4.23 & 6.55 & 44.50 \\
\hline & SER & 0.08 & 0.08 & 0 & 10.46 & 4.58 & 5.68 & 45.38 \\
\hline & VF1 & 1.13 & 1.38 & 0 & 36.00 & 5.08 & 5.08 & 55.25 \\
\hline & VF3 & 0.22 & 0.11 & 0 & 10.22 & 4.00 & 4.85 & 49.25 \\
\hline & VF5 & 0.60 & 0.70 & 0 & 19.70 & 5.08 & 4.23 & 40.75 \\
\hline \multicolumn{9}{|c|}{ December } \\
\hline & NEG & 0 & 0 & 1.00 & 23.11 & 5.60 & 6.00 & 18.00 \\
\hline & SER & 0 & 0 & 0 & 5.60 & 5.08 & 5.10 & 29.50 \\
\hline & VF1 & 0.57 & 0 & 0 & 21.16 & 4.83 & 5.00 & 31.00 \\
\hline & VF3 & 0 & 0.22 & 0 & 5.11 & 4.98 & 4.70 & 27.00 \\
\hline & VF5 & 0.20 & 0 & 0 & 12.41 & 5.53 & 4.45 & 26.50 \\
\hline \multicolumn{9}{|l|}{ January } \\
\hline & NEG & 0 & 0 & 4.61 & 15.57 & 6.23 & 5.90 & 44.25 \\
\hline & SER & 0.07 & 0 & 0 & 20.92 & 5.83 & 5.23 & 40.50 \\
\hline & VF1 & 0.13 & 1.00 & 0 & 19.70 & 6.25 & 5.03 & 56.00 \\
\hline & VF3 & 0 & 0 & 0 & 10.95 & 6.20 & 4.53 & 51.25 \\
\hline & VF5 & 0.50 & 0 & 0 & 9.24 & 6.23 & 4.15 & 55.75 \\
\hline \multicolumn{9}{|c|}{ Febreruary } \\
\hline & NEG & 0.21 & 0 & 3.42 & 18.00 & & 6.05 & 63.00 \\
\hline & SER & 0 & 0 & 0 & 14.60 & & 5.13 & 59.50 \\
\hline & VF1 & 2.00 & 1.55 & 0 & 17.27 & & 4.90 & 108.00 \\
\hline & VF3 & 0.63 & 0.38 & 0 & 4.87 & & 4.45 & 74.75 \\
\hline & VF5 & 0.60 & 0.20 & 0 & 9.73 & & 4.10 & 83.25 \\
\hline \multicolumn{9}{|l|}{ March } \\
\hline & NEG & 0 & 0 & 2.19 & 23.84 & & 6.25 & 36.00 \\
\hline & SER & 0.06 & 0.00 & 0 & 19.22 & & 5.15 & 54.50 \\
\hline & VF1 & 1.21 & 0.21 & 0 & 27.49 & & 5.08 & 37.25 \\
\hline & VF3 & 0 & 0 & 0 & 11.68 & & 4.70 & 48.00 \\
\hline & VF5 & 0.58 & 0.08 & 0 & 27.25 & & 4.40 & 39.75 \\
\hline \multicolumn{9}{|l|}{ April } \\
\hline & NEG & 0 & 0 & 2.82 & 27.49 & 7.60 & 6.30 & 40.50 \\
\hline & SER & 0.19 & 0.06 & 0 & 13.14 & 7.05 & 5.15 & 56.00 \\
\hline & VF1 & 0.80 & 0 & 0 & 18.73 & 6.68 & 5.20 & 45.75 \\
\hline & VF3 & 0.08 & 0.15 & 0 & 13.38 & 7.05 & 4.83 & 43.75 \\
\hline & VF5 & 0.45 & 0.09 & 0 & 25.54 & 7.78 & 4.55 & 37.00 \\
\hline \multicolumn{9}{|l|}{$\overline{\text { May }}$} \\
\hline & NEG & 0.06 & 0 & 4.83 & 29.37 & 7.00 & 6.95 & 37.75 \\
\hline & SER & 0.35 & 0 & 0 & 29.13 & 7.58 & 5.50 & 47.75 \\
\hline & VF1 & 2.50 & 2.00 & 0 & 36.41 & 8.25 & 5.10 & 36.75 \\
\hline & VF3 & 0.17 & 0 & 0 & 25.49 & 6.85 & 4.90 & 41.00 \\
\hline & VF5 & 1.18 & 0.09 & 0 & 26.94 & 7.93 & 4.33 & 68.50 \\
\hline \multicolumn{9}{|l|}{ June } \\
\hline & NEG & 0 & 0 & 3.08 & 85.14 & 5.90 & 6.90 & 43.00 \\
\hline & $\begin{array}{l}\text { SER } \\
\text { VF1 }\end{array}$ & 0 & 0.07 & 0 & 1.46 & 6.80 & 5.73 & 45.75 \\
\hline & VF3 & 0 & 0 & 0 & 12.89 & 6.20 & 5.20 & 37.00 \\
\hline & VF5 & 1.00 & 0 & 0 & 23.60 & 9.50 & 4.45 & 79.00 \\
\hline \multicolumn{9}{|l|}{ July } \\
\hline & NEG & 0.08 & 0 & 5.67 & 14.84 & 7.03 & 6.50 & 46.00 \\
\hline & $\begin{array}{l}\text { SER } \\
\text { VF1 }\end{array}$ & 0 & 0 & 0 & 5.60 & 6.95 & 5.60 & 43.00 \\
\hline & $\begin{array}{l}\text { VF3 } \\
\text { VF5 }\end{array}$ & 0 & 0 & 0 & 13.87 & 6.35 & 5.45 & 38.00 \\
\hline \multicolumn{9}{|l|}{ August } \\
\hline & NEG & 0 & 0 & 5.20 & 11.19 & 7.15 & 6.30 & 30.50 \\
\hline & SER & 0 & 0 & 0 & 5.35 & 6.90 & 5.70 & 36.25 \\
\hline & $\begin{array}{l}\text { VFI } \\
\text { VF3 }\end{array}$ & 0 & 0 & 0 & 10.46 & 5.20 & 5.55 & 26.50 \\
\hline & VF5 & & & & & & & \\
\hline
\end{tabular}

\footnotetext{
${ }^{a}$ is the total $\mathrm{P}$ concentration in the water column; ${ }^{b}$ is the dissolved oxygen concentration in the water column.
} 
Table 2. Variability (Var \%) in the abundance of $H$. guernei due to electrical conductivity (EC), dissolved $\mathrm{O}_{2}$ concentration $\left(\mathrm{O}_{2}\right)$, the total $\mathrm{P}$ concentration in the water column (TP) and the abundance of G. holbrooki (Gambusia). Beta-coefficients $(\beta)$, which indicate the sign of the effect (positive or negative), the standard errors of the Beta-coefficients $(\operatorname{SE}(\beta))$, the statistical values $(F)$, the degrees of freedom (Df.) and the $P$-values are also indicated. Variabilidad pura (Var \%) de la abundancia de H. guernei explicada por la conductividad eléctrica (EC), la concentración de $\mathrm{O}_{2}$ disuelto $\left(\mathrm{O}_{2}\right)$, la concentración del P total en la columna de agua (TP) y la abundancia de G. holbrooki (Gambusia). Se indican los Beta-coeficientes ( $\beta)$, indicando el signo de cada efecto (positivo o negativo), el error estándar de los Beta-coeficientes (SE ( $\beta)$ ), el valor del estadístico $(\mathrm{F})$, los grados de libertad (D.f.) y los $\mathrm{P}$-valores.

\begin{tabular}{lcccccc}
\hline & Df. & $F$ & Var $\%$ & $P$-value & $\beta$ & SE $(\beta)$ \\
\hline EC & 1 & 1.18 & 19.1 & 0.004 & 0.41 & 0.13 \\
O2 & 1 & 0.10 & 1.9 & 0.381 & 0.12 & 0.13 \\
TP & 1 & 0.44 & 8.1 & 0.067 & 0.25 & 0.13 \\
Gambusia & 1 & 0.84 & 14.5 & 0.013 & -0.35 & 0.13 \\
\hline
\end{tabular}

had only been previously recorded in the Azores archipelago on São Miguel Island (according to Borges et al., 2010). This fish is native to North America and was introduced as an exotic predator in freshwater habitats on all the continents around the world, excluding Antarctica (Pyke, 2005). This small exotic fish is a voracious predator of not only small prey such as invertebrates (Walters \& Legner, 1980) but also large prey such as tadpoles (e.g., Morgan \& Buttemer, 1996) and other small fishes (e.g., Ivantsoff, 1999). A multiple regression analysis revealed that the electrical conductivity and abundance of $G$. holbrooki exerted significant positive and negative effects, respectively, on the abundance of $H$. guernei, accounting for $19.1 \%$ and $14.5 \%$ of the variability, respectively (Table 2). Although we detected low values of conductivity in comparison with other Mediterranean temporary ponds (e.g., Florencio et al., 2013), the significant effects of these predictors on the abundance of $H$. guernei suggest a narrow species tolerance to environmental changes. Species of the genera $\mathrm{Hy}$ droporus typically occur in restrictive environments, such as acidic waters with low nutrient concentrations and Sphagnum-dominated vegetation (Verberk et al., 2001). However, we also demonstrate that the exotic fish $G$. holbrooki can influence the occurrence and abundance of $H$. guernei in certain ponds (NEG pond, Table 1). $G$. holbrooki generally feeds on aquatic beetle larvae and adults (Sokolov \& Chvaliova, 1936; Ozturk \& Ikiz, 2003; Erguden, 2013; Kalogianni et al., 2014), particularly those in the family Dytiscidae (Gkenas et al., 2012; Kalogianni et al., 2014). Thus, we suggest that the voracious behaviour of this exotic predator fish can potentially threaten pond endemicity on these oceanic islands. However, this affirmation must be confirmed by periodic monitoring in these ponds in the future. Although we detected the exotic fish in a permanent pond, the biodiversity of temporary ponds is not exempt from risks associated with mosquitofish invasion, as the species may eventually colonise these ponds during heavy rainfalls, when waterways may form that connect temporary and permanent ponds (e.g., Fahd et al., 2007).

\section{Implications for conservation}

In our study, we demonstrate the roles of temporary ponds in the context of pond endemicity on an oceanic island. These temporary ponds are free of fish, while both permanent ponds show evidence of fish. G. holbrooki was only recorded in the NEG pond. Although the study included a small number of ponds, we demonstrate that permanent ponds are likely more vulnerable to predator fish invasions. Such invasions require urgent monitoring actions, including control strategies for mosquitofish. These ponds require official recognition by conservation programmes, such as the Ramsar Convention. Studies encompassing freshwaters in the Macaronesian region are scarce; thus, further research should focus on temporal and spatial dynamics in freshwater systems to establish proper guidelines for conservation (Hughes \& Malmqvist, 2005).

\section{ACKNOWLEDGMENTS}

Laura Serrano performed the total phosphorous concentration analyses in the water column. Rui Elias and Rosalina Gabriel provided the technical equipment for $\mathrm{pH}$, dissolved oxygen concentrations and conductivity measurements in the water column. Paulo AV Borges provided 
material and support during the pond analyses on Terceira Island. We are grateful to Isabel Muñoz for comments that improved a previous version of the manuscript. We also appreciate the contributions of Marco Rosa and Adolfo Cordero for their support and comments as well as Luis Ansias, Sergio Fernández, Rui Carvalho, Herlander Lima and Will Sharkey for their assistance with fieldwork. We also thank Kieran Daniel Withey for reviewing the English. We thank the Direcção Regional da Ciência, Tecnologia e Comunicações (DRCT) for supporting the fellowship of M.F. (M3.1.7/F/002/2011) and the Fundación Barrie for the financial and academic support of L.L.L. M.F. is currently supported by the Conselho Nacional de Desenvolvimento Científico e Tecnológico-CNPq (401045/2014-5), Programa Ciência sem Fronteiras.

\section{REFERENCES}

ALLUAUD, C. 1891. Coléoptères recueillis aux Açores oar M. J. de Guerne pendant les campagne du yacht l'Hirondelle (1887-1888). Memoires de la Societe Zoologique de France, 4: 197-207.

ARRIBAS, R., C. DIAZ-PANIAGUA \& I. GOMEZMESTRE. 2014. Ecological consequences of amphibian larvae and their native and alien predators on the community structure of temporary ponds. Freshwater Biology, 59(9): 1996-2008.

BERNARD, A., C. D. ESCOBAR, A. MAZOT \& R. E. GUTIÉRREZ. 2004. The acid volcanic lake of Santa Ana volcano, El Salvador. In Natural hazards in El Salvador: Boulder, Colorado. Geological Society of America Special Paper, 375: 121-133.

BORGES, P. A. V., A. COSTA, R. CUNHA, R. GABRIEL, V. GONÇALVES, A. F. MARTINS, I. MELO, M. PARENTE, P. RAPOSEIRO, P. RODRÍGUEZ, R. S. SANTOS, L. SILVA, P. VIEIRA \& V. VIEIRA. 2010. A list of the terrestrial and marine biota from the Azores. Princípia, Cascais.

CASSEY, P., T. M. BLACKBURN, R. P. DUNCAN \& S. L. CHOWN. 2005. Concerning invasive species: reply to Brown and Sax. Austral Ecology, 30: 475480.

CLYMO, R. S. 1964. The origin of acidity in sphagnum bogs. Briologist, 67: 427-431.

DELMELLE, P. \& A. BERNARD. 1994. Geochemistry, mineralogy, and chemical modeling of the acid crater lake of Kawah Ijen Volcano, Indonesia. Geochimica et Cosmochimica Acta, 58(11): 24452460.

ERGUDEN, S. A. 2013. Age, growth, sex ratio and diet of eastern mosquitofish Gambusia holbrooki Girard, 1859 in Seyhan Dam Lake (Adana/Turkey). Iranian Journal of Fisheries Sciences, 12(1): 204-218.

FAHD, K., M. FLORENCIO, C. KELLER \& L. SERRANO. 2007. The effect of the sampling scale on zooplankton community assessment in temporary ponds and its implication for the conservation of temporary ponds in south-west Spain. Aquatic Conservation: Marine and Freshwater Ecosystem 17(2): 175-193.

FLORENCIO, M., L. SERRANO, C. GÓMEZ-RODRÍGUEZ，A. MILLÁN \& C. DÍAZ-PANIAGUA. 2009. Inter and intra-annual variations of macroinvertebrate assemblages are related to the hydroperiod in Mediterranean temporary ponds. Hydrobiologia, 634: 167-183.

FLORENCIO, M., C. DÍAZ-PANIAGUA, C. GÓMEZ-RODRÍGUEZ \& L. SERRANO. 2013. Biodiversity patterns in a macroinvertebrate community of a temporary pond network. Insect Conservation and Diversity, 4(7): 4-21.

GKENAS, C., A. OIKONOMOU, A. ECONOMOU, F. KIOSSE \& I. LEONARDOS. 2012. Life history pattern and feeding habits of the invasive mosquitofish, Gambusia holbrooki, in Lake Pamvotis (NW Greece). Journal of Biological ResearchThessaloniki, 17: 121-136.

GOLTERMAN, H. L. 2004. The chemistry of phosphate and nitrogen compounds in sediments. Kluwer Academic Publisher, Dordrecht, The Netherlands.

HEYER, W. R., M. A. DONNELLY, R. W. MCDIARMID, L.-A. C. HAYEK \& M. S. FOSTER. 1994. Measuring and monitoring biological diversity. Standard methods for amphibians. Smithsonian Institution Press, Washington.

HERMOSO, V., M. CLAVERO \& M. J. KENNARD. 2012. Determinants of fine-scale homogenization and differentiation of native freshwater fish faunas in a Mediterranean Basin: implications for conservation. Diversity and Distributions, 18: 236-247.

HUGHES, S. J. \& B. MALMQVIST. 2005. Atlantic Island freshwater ecosystems: challenges and considerations following the EU Water Framework Directive. Hydrobiologia, 544(1): 289-297. 
IVANTSOFF, W. 1999. Detection of predation on Australian native fishes by Gambusia holbrooki. Marine and Freshwater Research, 50(5): 467-468.

KALOGIANNI, E., S. GIAKOUMI, A. ANDRIOPOULOU \& Y. CHATZINIKOLAOU. 2014. Prey utilisation and trophic overlap between the non native mosquitofish and a native fish in two Mediterranean rivers. Mediterranean Marine Science, 15(2): 287-301.

LEGENDRE, P. \& L. LEGENDRE (1998) Numerical ecology: developments in environmental modelling $20,2^{\text {nd }}$ ed. Elsevier, New York.

LEPS, J. \& P. SMILAUER (2003) Multivariate Analysis of Ecological Data Using CANOCO. Cambridge University Press, New York City, New York.

MENDES, C. \& E. DIAS. 2001. Ecologia e Vegetação das Turfeiras de Sphagnum spp. da ilha Terceira (Açores). Comunidade Europea, Direcção Regional dos Recursos Florestais, Universidade dos Açores, Angra do Heroísmo.

MORGAN, L. A. \& W. A. BUTTEMER. 1996. Predation by the non-native fish Gambusia holbrooki on small Litoria aurea and L. dentata tadpoles. Australian Zoologist, 30(2): 143-149.

OZTURK, S. \& R. IKIZ. 2003. Some biological properties in the Akgöl (Fethiye-Muğla) population of the mosquitofish Gambusia affinis (Baird and Girard, 1853). Turkish Journal of Veterinary and Animal Science, 27: 911-915.

PYKE, G. H. 2005. A review of the biology of Gambusia affinis and G. holbrooki. Reviews in Fish Biology and Fisheries, 15(4): 339-365.

RAPOSEIRO, P. M., S. J. HUGHES, A. C. COSTA \& A. MAFALDA CRUZ. 2012. Azorean freshwater invertebrates: status, threats and biogeographic notes. Limnetica, 31(1): 13-22.
SOKOLOV, N. P. \& M. A. CHVALIOVA. 1936. Nutrition of Gambusia affinis on the rice fields of Turkestan. The Journal of Animal Ecology, 5(2): 390-395.

TIMPERLEY, M. H. \& R. J. VIGOR?BROWN. 1986. Water chemistry of lakes in the Taupo Volcanic Zone, New Zealand. New Zealand Journal of Marine and Freshwater Research, 20(2): 173-183.

VERBERK, W. C. E. P., G. J. A. VAN DUINEN, T. M. PEETERS \& H. ESSELINK. 2001. Importance of variation in water-types for water beetle fauna (Coleoptera) in Korenburgerveen, a bog remnant in the Netherlands. Proceedings of the Section Experimental and Applied Entomology-Netherlands Entomological Society, 12: 121-128.

VITOUSEK, P. M., C. M. D'ANTONIO, L. L. LOOPE \& R. WESTBROOKS. 1996. Biological invasions as global environmental change. American Scientist, 84: 468-478.

VITOUSEK, P. M., H. A. MOONEY, J. LUBCHENCO \& J. M. MELILLO. 1997. Human domination of Earth's ecosystems. Science, 277: 494-499.

WALTERS, L. L. \& E. F. LEGNER. 1980. Impact of the desert pupfish Cyprinodon macularius, and Gambusia affinis affinis on fauna in pond ecosystems. Hilgardia, 48(3): 1-18.

WELLBORN, G. A., D. K. SKELLY \& E. E. WERNER. 1996. Mechanisms creating community structure across a freshwater habitat gradient. Annual review of ecology and systematics, 27(1): 337-363.

WHITTAKER, R. J. \& J. M. FERNÁNDEZ-PALACIOS. 2007. Island biogeography: ecology, evolution, and conservation, $2^{\text {nd }}$ ed. Oxford University Press, Oxford.

WILLIAMS, D. D. 2006. The Biology of Temporary Waters. Oxford: Oxford University Press. 